\title{
Dan Zahavi
}

\section{Subjectivity and narrativity}

\begin{abstract}
English Summary
If the self - as a popular view has it - is a narrative construction, if it arises out of discursive practices, it is reasonable to assume that the best possible avenue to self-understanding will be provided by those very narratives. If I want to know what it means to be a self, I should look closely at the stories that I and others tell about myself, since these stories constitute who I am. In the following I wish to question this train of thought. I will argue that we need to operate with a more primitive and fundamental notion of self; a notion of self that cannot be captured in terms of narrative structures. In a parallel move, I will argue that there is a crucial dimension of what it means to be 'other' that is equally missed by the narrative approach. I will consequently defend the view that there are limits to the kind of understanding of self and others that narratives can provide.
\end{abstract}

\section{Dan Zahavi}

P.h.d. 1994, dr.phil. 1999, professor i filosofi ved Københavns Universitet. Hans primære forskningsfelt er fænomenologi og bevidsthedsfilosofi. Dan Zahavi har skrevet og redigeret mere end 15 bøger, heriblandt Husserl's Fanomenologi. Ny revideret udgave (2001), Fanomenologi (2003), Subjectivity and Selfhood (2005). Siden 2002 har Dan Zahavi været leder af Danmarks Grundforskningsfonds Center for Subjektivitetsforskning ved Københavns Universitet.

KeK 101 (2006), 74-94 


\section{Dan Zabavi}

\section{Subjektivitet og narrativitet}

Ifølge en for tiden populær antagelse er selvet en narrativ konstruktion. Hvis jeg ønsker at forstå, hvad det vil sige at være et selv, så bør jeg undersøge de historier som jeg og andre fortæller om mig selv, for disse historier konstituerer den jeg er. Jeg vil i det følgende problematisere denne tankegang. Jeg vil argumentere for at vi nødvendigvis må operere med et mere primitivt og fundamentalt begreb om selv, et begreb som ikke kan indfanges af eller reduceres til narrative strukturer. I en parallel bevægelse vil jeg hævde, at der er et afgørende aspekt ved det at være anden som den narrative tilgang også går fejl af. Jeg vil således forsvare det synspunkt, at der er grænser for den forståelse af selv og anden som fortællinger kan bibringe os.

\section{Det narrative begreb om selv}

Lad mig starte med en mere udførlig redegørelse for det narrative begreb om selv. En af de helt grundlæggende ideer er antagelsen om at vi må skelne mellem det at være bevidst og det at være et selv. Kravene til sidstnævnte er højere end til førstnævnte. Mere præcist, så er det at være et selv en præstation snarere end noget som er givet. Hvordan opnår man at blive et selv? Gennem en narrativ selvfortolkning. Nogle væsener væver deres liv sammen af historier, de organiserer og strukturerer deres oplevelser og handlinger narrativt; derved situerer de dem i en samlende historie, og det er netop herved at de konstitueres som selver. Det er derfor det at være et selv er ganske forskelligt fra det at være slank, 38 år, eller sorthåret. Hvem jeg er, er ikke noget givet, men derimod noget som realiseres igennem mine projekter. Hvem jeg er (i modsætning til hvad jeg er) er ikke et spørgsmål som kan besvares uafhængigt af hvordan jeg forstår og fortolker mig selv. For at sige det på anden vis, så bør ingen redegørelse for hvem man er forbigå ens egen selvfortolkning, da sidstnævnte er (delvis) konstitutiv for førstnævnte.

Som det klart fremgår, så forfæegter den narrative model ikke blot en erkendelsesteoretisk påstand. Jeg opnår en forståelse for, hvem jeg er, ved at placere mine karakteregenskaber, de værdier jeg tilslutter mig, de mål 
jeg forfølger, osv., indenfor en livshistorie som sporer deres oprindelse og udvikling; en livshistorie som fortæller, hvor jeg kommer fra og hvor jeg er på vej hen. Tilsvarende, så lærer jeg dig at kende via din livshistorie. Men grunden til at disse historier udgør en privilegeret måde at erhverve sig viden om selvet på, er netop fordi de konstituerer det. Som Bruner skriver »Selvet er formentlig det mest imponerende kunstværk vi nogensinde skaber, med sikkerhed det mest intrikate «. ${ }^{1}$ Fortællinger indfanger ikke blot aspekter af et allerede eksisterende selv. Der findes nemlig ikke et sådant forudgående præ-narrativt selv, et som blot venter på at blive beskrevet. At tro på eksistensen af et førsprogligt selv er helt bogstaveligt at være blevet ført bag lyset af historier.

Når det hævdes, at selvet er et produkt af et narrativt struktureret liv, at det er konstrueret i kraft af fortællinger, så skal denne påstand selv sagt ikke forstås som udtryk for, at man kun er et selv, hvis man har forfattet en selvbiografi. Selvbiografier er blot et litterært udtryk for den form for narrativ selvfortolkning som vi til stadighed er engageret i. Vi bør således skelne den implicitte form for fortælling som karakteriserer vores levede liv fra den bevidst artikulerede fortælling. For at min selvfortolkning skal kunne gxlde som narrativ kræves blot, ifølge Schechtman, at jeg forstår mine forskellige livsepisoder i kraft af deres placering i en fortælling, der er under udfoldelse. ${ }^{2}$ Det er et spørgsmål om at organisere mine oplevelser og handlinger på en måde, som implicerer en forståelse af mig selv som protagonist.

Den narrative redegørelse for selvet fremhæver helt eksplicit selvets tidslige og sociale dimension. Som Ricoeur har pointeret, så kan den specifikt menneskelige tidslighed hverken reduceres til bevidsthedens subjektive tid eller universets objektive tid. Derimod bygger den menneskelige tid bro mellem den fænomenologiske og den kosmologiske tid. Den menneskelige tid er den tid som artikuleres i vores livshistorier. Det er en tid som er struktureret og artikuleret af fortællingernes symbolske formidling. ${ }^{3}$ Hændelser og oplevelser som indtræffer på forskellige tidspunkter forenes ved at blive indføjet $i$ en samlende fortælling. Hvorvidt en specifik handling, oplevelse eller karakteregenskab gælder som min eller ej er således et spørgsmål om, hvorvidt den er inkluderet i min selvfortælling. ${ }^{4}$ Som MacIntyre også formulerer det, så beror selvets enhed på «enheden af en fortælling som knytter fødsel til liv til død som begyndelse til midte til slutning « ${ }^{5}$ eller som Husserl - en tænker man ikke normalt forbinder med den narrative tilgang - skriver, »jeget konstituerer sig så at sige for sig selv i historiens enhed ${ }^{6}{ }^{6}$

Det at fortælle historier er en social proces der starter i den tidlige barndom og som fortsætter resten af livet. Hvem man er, afhænger af 
de værdier, idealer og mål man har; det er et spørgsmål om hvad som har betydning og mening for en, og dette er selvsagt påvirket af det fællesskab man er del af. Som Bruner bemærker, så knytter de historier vi skaber os selv igennem an til konventionelle genrer. Når jeg taler om mig selv, så bliver mit selv en del af det offentlige domæne, og dets beskaffenhed formes af kulturelle antagelser om hvad et selv skal og ikke skal være. ${ }^{7}$ At lære sig selv at kende som et selv med en specifik livshistorie og bestemte karakteregenskaber er således både mere kompliceret end at kende til ens umiddelbare formodninger og ønsker og mindre privat end man umiddelbart skulle tro. ${ }^{8}$ Når jeg fortolker mig selv via en bestemt livshistorie, så kan jeg være såvel fortæller som hovedperson, men jeg er ikke eneforfatter. Begyndelsen af historien er altid allerede digtet af andre, og den måde som historien udfoldes på er kun til dels styret af mine egne valg og beslutninger. En hvilket som helst individuel livshistorie er ikke kun sammenvævet med andres historier (forældres, søskendes, venners), den er også indlejret i en mere omfattende historisk og kollektiv meningsstruktur. ${ }^{9}$ Jeg forstår mig selv som en arvtager og fortsætter af en tradition, eller som Husserl udtrykker det:

»...jeg er et 'barn af tiden', jeg er en del af et omfattende vi-fæellesskab; et fællesskab der har sin tradition og som på sin side er knyttet til de generative subjekter, til de nærmeste og fjerneste forfædre. Og de har 'påvirket' mig. Jeg er, hvad jeg er som arving. «10

Ricoeur, der ofte er blevet betragtet som en af den narrative models fremmeste fortalere, har til tider fremstillet sin egen narrative teori som en løsning på det klassiske dilemma om at skulle vælge mellem det Cartesianske begreb om selvet som et samlende identitetsprincip og Humes og Nietzsches positioner, der betragtede ideen om et identisk subjekt som en blot og bar substantialistisk illusion. ${ }^{11}$ Ricoeur foreslår at man kan undgå dette dilemma ved at erstatte det identitetsbegreb som henholdsvis forsvares og afvises med begrebet om narrativ identitet. Identiteten af det narrative selv afhænger af narrative konfigurationer. I modsætning til det sammes (idem) abstrakte identitet, kan den narrative identitet omfavne forandringer i løbet af en livstid. Vores livshistorie konfigureres og genkonfigureres af alle de sande og fiktive historier som subjektet fortæller om sig selv, og som Ricoeur skriver, gør dette »livet selv til et klæde vævet af fortalte historier « ${ }^{12}$ Men skønt det er ubestrideligt at Ricoeur har bidraget på afgørende vis til diskussionen om det narrative selv, så har han også eksplicit peget på nogle begrænsninger ved denne model. Som han skriver i Temps et récit, så er den narrative identitet navnet på et problem 
i mindst ligeså høj grad som den er navnet på en løsning. ${ }^{13}$

Som de fleste interessante teorier, er også den narrative model konfronteret med en række problemer. At fortælle en historie om ens eget liv er ikke blot en simpel fremstilling af de rå kendsgerninger, men indebærer derimod en fortolkning. ${ }^{14}$ Fortællinger er ikke blot optegnelser over det skete, men konstruerende fænomener som indbefatter forkortelser, redigeringer, slettelser og omstruktureringer. En fortæller vil typisk påtvinge vores livsepisoder en større grad af sammenhæng, integritet og afslutning end de besad da de blev gennemlevet. For at sige det på anden vis, så vil en fortælling nødvendigvis privilegere et særligt perspektiv på ens oplevelser og handlinger på bekostning af andre. Men for så vidt der ikke findes en simpel en-til-en korrelation mellem livet sådan som det leves og livet sådan som det fortælles, er man uvægerligt konfronteret med spørgsmålet om i hvilket omfang selvfortællinger kan siges at være sande eller falske. Det synes problematisk at hævde at selvfortællinger er selvopfyldende og derfor ufejlbarligt sande. Vi kan tage fejl om hvem vi er, og det synes oplagt at en persons oprigtige fortælling af en specifik livshistorie ikke garanterer dennes sandhed. Tværtimod kan stabiliteten af vores selvidentitet til tider være omvendt proportional med de fastlåste historier vi fortæller om os selv. Udførlige historier kan tjene et kompensatorisk formål, kan være et forsøg på at kompensere for skrøbeligheden af ens selvidentitet. Men givet at vores selvfortællinger er fejlbarlige, er de da udelukkende holdt i skak af andres fortællinger om os, eller kan man også appellere til fortællingstranscenderende forhold?

Dette spørgsmål er selvsagt relateret til kontroversen om, hvorvidt den narrative model forpligter en til et realistisk eller fiktionalistisk syn på selvet. Nogle fortalere for den narrative model har med Dennetts berømte formulering hævdet, at selvet blot er den narrative tyngdekrafts fiktive centrum. Det er blot det abstrakte punkt hvor forskellige historier krydser hinanden. ${ }^{15}$ Tilsvarende er det blevet hævdet, at fortællinger blot reflekterer vores behov for en tilfredsstillende sammenhæng og at de forvansker virkeligheden ved at påtvinge livet - der i sig selv hverken har en begyndelse, midte eller slutning - sådanne strukturer. ${ }^{16}$ I modsætning hertil har andre hævdet, at det narrative selv er virkeligt for så vidt som det er en virkelig social konstruktion. Det er også blevet hævdet at skønt der er oplagte forskelle mellem fiktive og virkelige fortællinger - i livet må vi tage tingene som de kommer, vi er midt i hændelserne, og er afskåret fra det autoritative tilbageblik som historikeren eller historiefortælleren besidder ${ }^{17}$ - ja så kan de narrative konfigurationer ikke desto mindre ses som en udvidelse og berigelse af de strukturer som vores oplevelser og handlinger allerede besidder. ${ }^{18}$ Den levede tid har f.eks. allerede en kvasi- 
narrativ struktur, hvilket er grunden til at den ikke er modtagelig for en hvilken som helst fortælling. Det er således ikke forsøget på at forfægte at vores liv skulle have sammenhæng, men forsøget på at benægte dette, som må betegnes som fantasifuldt. ${ }^{19}$

Det vil føre for vidt at skulle afklare alle disse spørgsmål i det følgende, så jeg vil i stedet fokusere på et yderligere problem som imidlertid har relevans for de netop nævnte. Selvfortællinger kan givetvis fortælle os vigtige ting om selvet, men kan den narrative model levere en udtømmende forklaring på, hvad det vil sige at være et selv? Er det legitimt at reducere vores selv til det som kan fortælles? Er det muligt at undgå fiktionalismen, hvis selvet betragtes som en blot og bar narrativ konstruktion? Som vi allerede har set, kombinerer den narrative model sædvanligvis en erkendelsesteoretisk og ontologisk tese. Jeg har som sådant ikke noget problem med nogle af teserne, og heller ikke med deres kombination. Jeg medgiver gerne at fortællinger er et centralt middel til at lære sig selv og andre at kende. Jeg tror sådanne fortællinger afspejler vores selvforståelse og derfor også vores selvidentitet. Men der er forskel mellem at hævde, at fortællinger kan redegøre for visse aspekter af selvet, og at hævde at de kan indfange alt. Jeg vil modsætte mig sidstnævnte påstand. Jeg vil modsætte mig påstanden om at selvet er en narrativ konstruktion og at enhver tilgang til selvet og andre sker via fortællinger. Det er netop den slags radikale udsagn man kan finde hos en række af fortalerne for den narrative model. Som Wilhelm Schapp for eksempler erklærer i sit klassiske værk In Geschichten Verstrickt: Det menneskelige liv er indfanget og indvævet i historier, det er intet ved siden af disse historier, og sådanne historier udgør den eneste mulige tilgang til selv og til andre. ${ }^{20}$

\section{Det oplevelsesmessige selv}

En redegørelse for selvet som opererer ud fra en antagelse om, at der kun er ét niveau eller aspekt af selvet som der skal tages højde for, er uhørt forsimplet. Det første trin i min argumentation vil være at vise, at det er nødvendigt at tilgodese en anden dimension af hvad det vil sige at være et selv, end den som den narrative model søger at redegøre for. Dette er som sådan ikke en ny ide. Indenfor de seneste år har både Damasio og Metzinger argumenteret på lignende vis.

I The Feeling of What Happens hævder Damasio at oplevelsen af selv er en uomgængelig del af vores bevidsthed. Som han skriver, "Hvis 'selvbevidsthed' betyder 'bevidsthed med en oplevelse af selv' så dækker termen nødvendigvis enhver form for menneskelig bevidsthed « ${ }^{21}$ Når jeg tænker på månens bagside, læser en tekst, betragter en vindueskarm, en 
rød cykel, eller en dampende kop te, så oplever jeg automatisk og implicit at det er mig, snarere end nogen anden som gør det. Jeg oplever at de genstande som jeg nu betragter opfattes fra mit perspektiv og at de tanker som formes i min bevidsthed er mine og ikke nogen andens. Så ifølge Damasio, er mit bevidste liv karakteriseret ved et konstant, men stiltiende, selvnærvær. ${ }^{22}$

Bevidstheden er imidlertid ikke monolitisk og Damasio argumenterer også for at vi må skelne en simpel fundamental form, som han kalder kernebevidsthed fra en mere kompleks form, som han kalder udvidet bevidsthed. Kerne bevidstheden har et enkelt organisationsniveau og forbliver stabilt igennem organismens livsforløb. Den er ikke eksklusivt menneskelig og er ikke afhængig af almindelig hukommelse, arbejdshukommelse, tænkning eller sprog. I modsætning hertil har den udvidede bevidsthed adskillelige organisationsniveauer. Den forandres og udvikles i løbet af organismens livsforløb og forudsætter både almindelig hukommelse og arbejdshukommelse. Den kan findes i rudimentær form hos nogle dyr, men opnår først sin højeste form hos sprogbrugende mennesker. For Damasio er disse to former for bevidsthed knyttet til to former for selv. Han kalder den form for selv der opstår i kernebevidstheden for kerneselvet, og omtaler den mere komplicerede form for selv, som den udvidede bevidsthed muliggør, for det selvbiografiske selv. ${ }^{23}$ Fra et udviklingspsykologiske perspektiv er der ved livets begyndelse kun et kerne selv tilstede, men som oplevelserne hober sig op, vokser hukommelsen og det selvbiografiske selv dannes. ${ }^{24}$

Der er - i det mindste ved første øjekast - et ret slående sammenfald mellem Damasios overvejelser og den position som Metzinger for nylig har forsvaret i bogen Being No One. Metzinger argumenterer også for en tæt forbindelse mellem det at være et selv, og det at have selverfaring og besidde et første-persons perspektiv. Når man er ved bevidsthed oplever man at være nogen. Men den fænomenologi som knytter sig til det at være nogen er en perspektivitetens fænomenologi. Vores oplevelsesmæssige liv besidder et fokus, et perspektiv. Det er et første-persons perspektiv i den forstand at det er knyttet til et selv. Det giver således, ifølge Metzinger, ingen mening at tale om et første-persons perspektiv uden samtidig at tale om et selv. ${ }^{25}$ Men hvad beløber dette oplevelsesmæssige selv sig så til? Metzinger skriver at der synes at være en primitiv og førrefleksiv form for fænomenal selvbevidsthed som ligger til grund for alle højere-ordens og begrebsligt formidlede former for selvbevidsthed. Denne førrefleksive selvfortrolighed kan betragtes som en meget primitiv, basal og spontan form for selvnærvær; den kommer bl.a. til udtryk i den oplevelse af minhed som ledsager kropslige fornemmelser, følelses- 
mæssige tilstande og kognitivt indhold. I ikke-patologiske tilfælde synes alle disse mentale tilstande således automatisk at blive oplevet subjektivt som ens egne tilstande, som momenter af ens egen bevidsthedsstrøm. Denne selvoplevelse adskiller sig fra alle andre oplevelsesindhold ved sin invariante beskaffenhed. I modsætning til duften af knuste mynteblade eller smagen af kærnemælk er den altid til stede. Den vil dog sjældent blive eksplicit bemærket, men vil som regel figurere i baggrunden som et subtilt nærvær. ${ }^{26}$

Damasio og Metzinger har begge leveret interessante analyser, men fra et rent deskriptivt perspektiv indeholder deres overvejelser intet nyt. I begge tilfæxlde har vi at gøre med en reformulering og (ufrivillig) gentagelse af ideer som allerede kan findes i den klassiske fænomenologi. For at sige det på en anden måde, så finder man det mest eksplicitte forsvar og analyse af hvad man kan kalde det oplevelsesmæssige selv hos tænkere som Husserl, Heidegger, Sartre, Merleau-Ponty og Michel Henry. Lad mig give et par konkrete eksempler.

I L'être et le néant hævder Sartre at vores bevidsthed er karakteriseret ved en fundamental selvgivethed eller selvreference som han betegner med termen ipseitet (fra det latinske ipse som betyder selv). ${ }^{27}$ Han skriver endvidere, »Den førrefleksive bevidsthed er en selvbevidsthed. Det er dette begreb om selv som man skal studere, for det definerer selve bevidsthedens væren «. ${ }^{28}$ Når Sartre taler om selvet, så refererer han således til noget ganske grundlæggende, noget som karakteriserer oplevelsesstrømmen som sådan. Skønt det er noget jeg kan undlade at artikulere og tematisere, er det ikke noget jeg kan undslå mig at være.

I Phénoménologie de la perception taler Merleau-Ponty til tider om subjektet som virkeliggørende sin ipseitet i sin kropslige væren-i-verden. ${ }^{29}$ Han refererer imidlertid også til Husserls undersøgelse af den indre tidsbevidsthed og skriver at den tidslige strømmen er den mest fundamentale form for selvrelation og at netop den afsætter eller udstikker en inderlighed eller et selv. En side senere hedder det at bevidstheden altid afficeres af sig selv, og at selve ordet »bevidsthed « bliver meningsløst, hvis det isoleres fra denne fundamentale selvgivethed. ${ }^{30}$

I begyndelsen af de såkaldte Bernaner Manuskripte über das Zeitbewusstsein som først for nyligt er blevet udgivet, skriver Husserl at bevidstheden eksisterer, at den eksisterer som en strøm, og at den fremtræder for sig selv som en strøm. Men hvordan bevidsthedsstrømmen formår at være bevidst om sig selv, hvordan det er muligt og forståeligt at selve strømmens væren er en form for selvbevidsthed er, som Husserl bemærker, et spørgsmål der vedbliver med at trænge sig på. ${ }^{31}$ Husserls undersøgelser af tidsligheden er i høj grad motiveret af hans interesse for spørgsmålet 
om hvordan bevidstheden er givet for sig selv, hvordan den manifesterer sig selv. Det vi finder hos Husserl er således en fokuseret undersøgelse af forholdet mellem selvet, den oplevelsesmæssig selvgivethed og tidsligheden. Hans analyse af strukturen protention, urimpression, retention bør f.eks. forstås som en strukturel analyse af vores oplevelsers førrefleksive selvgivethed. ${ }^{32}$

Ifølge Michel Henry, for nu blot at nævne et enkelt eksempel til, er det på sin plads at tilskrive en fundamental form for ipseitet til de oplevelsesmæssige frnomener netop fordi bevidstheden som sådan er karakteriseret ved en primitiv og basal selvbevidsthed. Det er fordi subjektiviteten manifesterer sig for sig selv at den er et selv. ${ }^{33}$ Henry knytter således begrebet om selv sammen med oplevelsernes første-personlige givethed og skriver at den mest fundamentale form for selv er den som er konstitueret af oplevelsernes selvgivethed.

Den gennemgående ide hos alle disse fænomenologer er, at en forståelse af hvad det vil sige at være et selv fordrer en undersøgelse af oplevelsernes struktur og vice versa. Selvet er således ikke noget som står overfor bevidsthedsstrømmen, men er snarere et gennemgående strukturmoment heraf. Mere præcist, så hævdes det at det minimale selv eller kerne selvet, for nu at bruge Damasios udtryk, besidder oplevelsesmæssig realitet, det er tæt knyttet til første-persons perspektivet og bliver netop identificeret med de oplevelsesmæssige fænomeners første-personlige givethed; en givethed som ikke er oplevelserne uvedkommende, noget som de kunne mangle og stadig vedblive med at være oplevelser, men som tværtimod er det som gør dem subjektive.

Selverfaring - i den mest primitive betydning af ordet - er et spørgsmål om at have subjektiv fortrolighed med ens egen bevidsthed; det er et spørgsmål om det oplevelsesmæssige livs første-personlige givethed eller manifestation. De fleste vil medgive at det føles på en bestemt måde for et subjekt at have eller gennemleve bestemte oplevelser (at smage vandbakkelser, at være glad, at erindre sig et besøg i Tivoli). Men for så vidt som det føles på en bestemt måde for subjektet at gennemleve disse oplevelser, må subjektet også have en subjektiv tilgang eller adgang til oplevelserne; det må være fortrolig med dem. Skønt oplevelsernes fænomenale kvalitet varierer - duften af knuste mynteblade føles på en anden måde end synet af en solopgang eller oplevelsen af Lalos Symphonie Espagnole - så har de også fællestræk. Et af disse af kvaliteten af minhed (eller for at bruge Heideggers udtryk Jemeinigkeit). Oplevelserne er (i det mindste implicit) givet som mine oplevelser, som oplevelser jeg gennemlever. Oplevelser er, med andre ord, ikke blot karakteriseret ved bestemte kvalitative træk, de er også karakteriseret ved det forhold at de nødvendigvis eksisterer for 
et subjekt eller selv, de er nødvendigvis givet for nogen. Oplevelsernes første-personlige givethed implicerer således en primitiv form for iboende selvreference. Jeg oplever ikke først en tandpine eller smagen af blomkål for så siden hen at måtte spørge: »Hvis oplevelse er det egentlig?» Og om den pågældende oplevelse er oplevet som min eller ej, afhænger ikke af noget fra oplevelsen forskelligt, men derimod af den måde som oplevelsen er givet på. Hvis oplevelsen er karakteriseret ved en første-personlig givethed, så er den givet som min oplevelse, ellers ikke. Det synes på den baggrund oplagt at definere det oplevelsesmæssige selv som den invariante dimension af første-personlig givethed i mangfoldigheden af vekslende oplevelser.

En sådan definition gør det samtidig klart, at det ville være en misforståelse at udlægge det fænomenologiske begreb om et minimalt oplevelsesmæssigt selv som en form for Cartesiansk residuum, som en form for selvindesluttet eller selvtilstrækkelig inderlighed. Det fænomenologiske begreb om selv er fuldt foreneligt med en markant fremhævelse af bevidsthedens fundamentale intentionalitet eller væren-i-verden. Det er ikke noget tilfælde at selv Heidegger gør flittigt brug af dette minimale begreb om selv, f.eks. i den tidlige forelæsningsrække Zur Bestimmung der Philosophie. ${ }^{34}$

Rent deskriptivt er der en slående lighed mellem Damasio, Metzinger og fænomenologerne. Men der stopper enigheden også. Damasio hævder at selvet er et uomgxngeligt aspekt ved den menneskelige bevidsthed og han betragter bevidstheden og dens konstituerende dele som virkelige snarere end som illusioner. ${ }^{35}$ Fænomenologerne hævder, at selvet er virkeligt for så vidt det har oplevelsesmæssig virkelighed, og at gyldigheden af vores redegørelse afhænger af dens evne til at være tro mod erfaringen, af dens evne til at indfange og artikulere (invariante) oplevelsesmæssige strukturer. I modsætning hertil forsvarer Metzinger det synspunkt, at det ville være en fejlslutning (og udtryk for hvad han kalder en fænomenologisk tingsliggørelse) at slutte fra indholdet og strukturen af den fænomenale selverfaring til konkrete egenskaber ved et indre ikke-fysisk objekt, hvilket tilsyneladende er hvad Metzinger mener at selvet må være (hvis det altså overhovedet havde eksisteret). ${ }^{36}{ }^{37}$ For Metzinger hævder nemlig også at en fænomenologisk redegørelse for selvet fuldstændig savner metafysisk gennemslagskraft. Vores selverfaring, vores primitive førrefleksive følelse af at være et bevidst selv, er aldrig sandfærdig, og Metzinger kan derfor skrive at hans centrale påstand er, at selvet slet ikke er virkeligt, men derimod en - særdeles vedholdende - illusion. ${ }^{38}$

Jeg har andetsteds udførligt kritiseret Metzingers eliminativisme, ${ }^{39}$ så lad mig her blot vende tilbage til hovedspørgsmålet. Er selvet en narrativ 
konstruktion? Er fortællinger den primære (og måske sågar eneste) tilgang til selvet? Det skulle nu være oplagt, hvorfor jeg vil svare benægtende på disse spørgsmål. Det oplevelsesmæssige selv er ikke et produkt af vores narrative praksisser. Det er en integreret del af vores fænomenale bevidsthed og må betragtes som en førsproglig forudsætning for sådanne praksisser. Kun et væsen med et første-persons perspektiv kan betragte sine mål og idealer som sine egne og fortælle en historie herom. Når vi taler om et første-persons perspektiv er det derfor også afgørende at skelne mellem at besidde et sådant perspektiv og være i stand til sprogligt at udtrykke det (man kunne her eventuelt skelne mellem et svagt og et stærkt første-persons perspektiv). Mens sidstnævnte forudsætter beherskelse af første-persons pronominet, er førstnævnte blot et spørgsmål om at have subjektiv adgang til ens egne oplevelser. Eller for at sige det anderledes: Den sproglige selvreference artikulerer selvbevidsthed, den frembringer den ikke. ${ }^{40}$

Nogle af narrativisterne indrømmer eksistensen af et sådan svagt førstepersons perspektiv, men de synes ikke at indse dets vigtighed og drager heller ikke den fornødne konsekvens, nemlig at denne primitive struktur fortjener at blive kaldt et selv. I Time, Narrative, and History, medgiver Carr, for eksempel, at oplevelser og handlinger allerede må være givne som mine, hvis jeg skal kunne bekymre mig om, hvordan de hænger sammen og om hvorvidt de udgør en kohærent livshistorie, men som han så tilføjer, så udgør en sådan oplevet enhed kun en nødvendig og ikke en tilstrækkelig betingelse for det at være et selv. ${ }^{41}$ I Narrative and the Self, skriver Kerby at forsøget på at forklare selvet med henvisning til tidsbevidsthedens fundamentale strukturer svarer til at ville beskrive et hus blot med henvisning til dets facade og fundament. Han finder ikke en sådan redegørelse for det menneskelige selv tilfredsstillende. ${ }^{42}$ Man kan dog uden videre acceptere, at der er mere ved det at være menneske end det at besidde et første-persons perspektiv, og samtidig fastholde at det ikke er særlig bekvemt at bo i et hus uden fundament. Endelig, for nu blot at nævne et enkelt yderligere eksempel, i Making Stories indrømmer Bruner at visse træk ved selvet er medfødte og at vi derfor må anerkende eksistensen af et primitivt, førbegrebsligt selv, men han fastholder samtidig at dysnarrativia (som vi f.eks. kan støde på i Alzheimers eller i Korsakoffs syndrom) er dræbende for selvet og at der ikke ville være noget selv, hvis vi manglede narrative evner. ${ }^{43}$

Man kan undre sig over at Bruner ikke foretager den oplagte bevægelse og ganske enkelt indrømmer, at man bør operere med forskellige komplementerende selvbegreber, men samtidig må man også stille spørgsmålstegn ved hans henvisninger til neuropatologi. Alzheimers er 
en tiltagende degenerativ hjernesygdom som bl.a. medfører vidtgående hukommelsestab, ændringer i adfærd og tænkning, og en helt generel funktionstilbagegang. ${ }^{44}$ Personen som lider af Alzheimers vil således have en lang række kognitive defekter; evnen til at forstå og anvende sprog (og fortællinger) vil kun være et af de berørte områder. Så selv hvis der ikke skulle forblive noget selv i de fremskredne stadier af Alzheimers er det altså ingenlunde givet, at det er dysnarrativiteten som er den afgørende årsag. (Hvis man var på udkig efter en lidelse som ganske selektivt berørte de narrative evner, ville global afasi være en mere oplagt kandidat; men igen, hvem ville hævde at den som rammes af global afasi ophører med at være et selv?). Derudover er der tale om et stort hvis. Det er på ingen måde indlysende at Alzheimers rent faktisk medfører en total ødelæggelse af første-persons perspektivet, en fuldstændig tilintetgørelse af minhedsdimensionen, og at enhver oplevelse der måtte forblive er ejerløs og anonym, således at enhver smerte og ethvert ubehag der opleves ikke længere opleves som tilhørende en selv. Det er næppe uden betydning at erfarne klinikere hævder at patienter med Alzheimers adskiller sig fra hinanden og at enhver der lider af sygdommen gør det på sin egen måde. ${ }^{45}$ Hvis det skulle vise sig, at der forbliver et intakt selv, og hvis Alzheimers samtidig rent faktisk involverer en form for dysnarrativitet, ja så må man nødvendigvis konkludere lige akkurat modsat af Bruner. Man må konkludere at der er mere ved det at være et selv, end hvad den narrative model er i stand til at indfange. Ikke overraskende er dette også Damasios påstand. Damasio hævder således at neuropatologien kan levere empirisk belæg for hans egen distinktion mellem kerne selv og udvidet selv. Neuropatologien afslører at kerne bevidstheden kan fungere intakt selv når den udvidede bevidsthed er svækket eller helt mangler, mens en svækkelse eller decideret tab af kerne bevidstheden også får den udvidede bevidsthed til at kollapse. ${ }^{46}$

En mulighed er nu at skelne mellem det minimale oplevelsesmæssige selv og det udvidede narrative selv. En anden option er at bibeholde termen »selv « når vi taler om det oplevelsesmæssige selv - her er der jo eksplicit fokus på en primitiv form for selvgivethed eller selvreferentialitet - og i stedet tale ikke om selvet, men om personen som en narrativ konstruktion. Det som den narrative model primært er fokuseret på er jo netop beskaffenheden af min personlighed, en personlighed som udvikler sig over tid, og som formes af de værdier jeg tilslutter mig og af mine etiske og intellektuelle overbevisninger og beslutninger. ${ }^{47}$

Det forhold at det narrative selv (altså personen) forudsætter det oplevelsesmæssige selv (men ikke vice versa) formindsker ikke betydningen af førstnævnte. Oplevelsernes første-personlige givethed sikrer at vores 
bevidsthedsstrøm er individueret fra bunden af. Det forbliver imidlertid en rent formal form for individuation. En beskrivelse af mit oplevelsesmæssige selv vil således ikke adskille sig væsentlig fra en beskrivelse af dit oplevelsesmæssige selv, bortset fra på det punkt, at det første er en beskrivelse af mig, det anden en beskrivelse af dig. En langt mere håndgribelig form for individualitet etablerer og manifesterer sig derimod i min personlige historie, i mine overbevisninger og beslutninger. Disse beslutninger og overbevisninger former min karakter. Jeg forbliver den samme så længe jeg er mine overbevisninger tro, når de ændres, ændrer jeg mig også. ${ }^{48}$ Idealer kan således være identitetsdefinerende. At handle mod sine idealer kan medføre en disintegration (i betydningen dys-integritet) af ens helhed som person. ${ }^{49}$

Personer eksisterer ikke i et socialt vakuum. At eksisterer som person er at eksistere socialiseret i et fællesskab, hvor ens forhold til sig selv er overtaget fra andre. Jeg bliver netop en person i kraft af mit liv sammen med andre i en fælles verden. Som Husserl, en bemærkelsesværdig mangesidig tænker, bemærker:

"Personligheden har sin oprindelse i empatien og i de herfra fremvoksende sociale akter. For at være en person er det ikke tilstrækkeligt at subjektet bliver sig selv bevidst som aktpol; personligheden konstituerer sig først når subjektet indtræder i sociale forbindelser med andre subjekter. ${ }^{50}$

Normalt vil det selv som vi undersøger altid allerede være personaliseret eller i det mindst på vej til at udvikle sig til en person. Men skønt et snævert fokus på det oplevelsesmæssige selv derfor kan siges at implicere en form for abstraktion, er der ikke grund til at betvivle dets realitet. Der er ikke tale om en blot abstraktion. Det oplevelsesmæssige selv udgør ikke blot fundamentet for andre mere komplekse aspekter eller dimensioner af selvet; det er også et begreb som har demonstreret sin empiriske relevans, f.eks. i skizofreniforskningen. ${ }^{51}$

\section{Fortellinger og fremmedhed}

Jeg har indtil videre diskuteret forholdet mellem fortællinger og selvet. Men hvad med vores møde med andre? Forstår vi ikke netop andres handlinger ved at indplacere dem indenfor rammerne af en fortælling? Er vores evne til at forstå andre ikke i høj grad, sådan som Hutto og Bruner har hævdet, støttet og lettet af vores fælles fortællinger og af vores forståelse af hvordan en mangfoldighed af karaktertyper reagerer i forskellige 
narrative scenarier? ${ }^{52}$

Jeg vil gerne medgive at den såkaldte Narrative Practice Hypothesis udgør et lovende alternativ til standard optionerne i Theory of Mind debatten, ${ }^{53}$ men jeg tror også, at der er grænser for hvor langt fortællingerne kan bringe os. Lad mig i det følgende kort nævne to af mine forbehold.

Det første forbehold er ganske trivielt. Fra et udviklingspsykologisk perspektiv virker der problematisk at hævde, at fortællinger er roden og fundamentet for enhver intersubjektivitet. Børn erhverver sig først narrative færdigheder på et relativt sent tidspunkt, men allerede fra fødslen af deltager de i stadig mere sofistikerede former for social interaktion. Øjenkontakt og ansigtsudtryk spiller en afgørende rolle for spædbarnet, som allerede kort efter fødslen er i stand til at skelne moderens ansigt fra fremmedes ansigter. To til tre måneder gamle spædbørn vil initiere «protosamtaler « med andre mennesker ved at smile og vokalisere. Der synes ikke at være andre formål med denne tidlige interaktion end interaktionen selv og den affektive resonans som den muliggør. Når en moder matcher barnets affekter, vil barnet respondere, og vise sensitivitet overfor moderens eget emotionelle udtryk. Spædbarnet har klare forventninger til, at modparten samarbejder aktivt med det for at opretholde og regulere interaktionen. Hvis moderen forholder sig ubevægeligt og passivt, vil barnet ophøre med at smile og vil udvise bekymring og forsøge at genvinde hendes deltagelse. ${ }^{54}$

Fra omkring 9-måneders alderen kan spædbørn demonstrere fælles opmærksomhed (joint attention). De kan følge en anden persons blik eller pegende finger, og når de gør det, vil de ofte se tilbage på personen og via feedbacket fra hans eller hendes ansigtsudtryk søge at få bekræftet, at de rent faktisk har identificeret den rigtige genstand. De kan også finde på at fremvise genstande til andre og ser ofte personen i øjnene for at kontrollere om vedkommende er opmærksom.

Disse eksempler - og der er mange flere - illustrerer former for intersubjektivitet, der går forud for den narrativt baserede sociale interaktion.

En mulig indvending kunne nu være, at skønt der her endnu ikke er tale om fuldt udviklede former for narrativitet, så er der stadig noget på færde som man kunne kalde mikro-narrativer. Udvekslingerne er strukturerede som meningsfulde forløb med en begyndelse og en slutning. Dette svar ligger i fin forlængelse af en generel strategi vi allerede er stødt på. Husk på at en række af narrativisterne, i et forsøg på at øge plausibiliteten af deres egen position, fandt det opportunt at skelne bevidst artikulerede fortællinger fra de implicitte kvasi-narrativer som karakteriserer vores le- 
vede liv. Tilsvarende, $\mathrm{i}$ et forsøg på at distancere sig fra fiktionalismen, har flere af dem hævdet, at den narrative struktur begyndelse-midte-slutning må ses som en udvidelse og berigelse af den tidslige konfiguration som allerede karakteriserer vores oplevelser og handlinger. ${ }^{55}$ Problemet med dette svar er, at det ved at løsne koblingen mellem sprog og fortælling strækker sidstnævnte begreb mere end det kan holde til. Begrebet «fortælling « bliver så udvandet, at det bliver indholdsløst - i sidste ende er alt meningsfuldt narrativt - og dette er vel et tegn på strategiens sammenbrud.

En anden indvending kunne gå på, at ingen af de nævnte eksempler konklusivt viser at spædbarnet er i besiddelse af en egentlig forståelse af distinktionen mellem selv og anden og at en sådan forståelse - som er en forudsætning for at kunne tale meningsfuldt om intersubjektivitet - først muliggøres af sprogbrug og fortællinger. Det ville føre for vidt hvis jeg skulle diskutere denne indvending i detaljer her, så lad mig blot henvise til udviklingspsykologer som Daniel Stern og Philippe Rochat, der i mine øjne, begge har argumenteret overbevisende for at spædbørn allerede kort efter fødslen er i stand til at skelne mellem selv og anden. ${ }^{56}$

Lad mig fortsætte til mit andet forbehold, som jeg vil bruge lidt mere tid på. I modsætning til hvad der synes at være det dominerende synspunkt i den igangværende Theory of Mind-debat, har de fleste fænomenologer hævdet, at det er muligt at erfare andres følelser, ønsker og formodninger i deres udtryksmæssige adfærd. ${ }^{57}$ At jeg kan have en regulær erfaring af et andet bevidst subjekt, og ikke må nøjes med en blot teoretisk slutning hertil eller en intern simulation heraf, implicerer imidlertid ikke, at jeg kan erfare den anden på samme måde som hun selv gør, ligesom det heller ikke betyder, at den andens bevidsthed er mig tilgængelig på samme måde som min egen er. Anden- (og tredje-) persons perspektivet på psykologiske tilstande er forskellige fra første-persons perspektivet, men denne forskel er ikke en mangel eller brist; derimod er der tale om en konstitutionel forskel. Det er en forskel som netop gør den pågældende erfaring til en erfaring af et andet subjekt, snarere end til en selverfaring. Som Husserl skriver, havde jeg den samme adgang til en andens bevidsthed som jeg har til min egen, ville den anden ophøre med at være anden og i stedet blive en del af mig selv. ${ }^{58}$ At kræve mere, at fordre at jeg kun kan have en regulær erfaring af andre subjekter, hvis jeg kan erfare deres oplevelser på samme måde som de selv gør det, er absurd. Det ville medføre, at jeg kun kan erfare andre, hvis jeg erfarer dem på samme måde som jeg erfarer mig selv, og dermed føre til en ophævelse af forskellen mellem selv og anden. Vi må altså respektere den særlige beskaffenhed af det fremmede subjekts givethed. Vi erfarer andres meningsfulde adferd 
som udtrykkende psykologiske tilstande, der transcenderer den adfærd som udtrykker dem. Både Sartre og Lévinas har insisteret på at den andens andethed kommer til udtryk i netop denne transcendens.

Ifølge Sartre må enhver tilfredsstillende redegørelse for intersubjektiviteten respektere den andens transcendens. En traditionel indfaldsvinkel på det klassiske fremmedpsykiske problem har været at stille spørgsmålet om, hvordan det er muligt at erfare andre, men ifølge Sartre er dette en forkert måde at håndtere problemet på. Sartre hævder, at det er helt afgørende at skelne mellem den anden som jeg betragter og den anden som betragter mig, dvs. mellem den anden som objekt og den anden som subjekt. Det virkeligt unikke og særegne ved mødet med den anden er ikke, at jeg her erfarer en genstand som selv er bevidst, men derimod at jeg møder et fremmed subjekt som transcenderer mit greb om vedkommende og som netop er i stand at percipere og objektivere mig. Snarere end at fokusere på den anden som en særlig genstand for vores empati, som en vi kan gribe og indfange via fortællinger, betoner Sartre at den virkeligt anden, den anden-som-subjekt, netop er den for hvem jeg selv optræder som objekt, og at det er når jeg erfarer min egen objektivitet (for og overfor et fremmed subjekt) at den anden-som-subjekt er givet for mig med evidens. ${ }^{59}$

I sin analyse af intersubjektiviteten fremhæver Sartre den andens transcendente og flygtige karakter, og afviser ethvert forsøg på at bygge bro mellem eller bagatellisere forskellen mellem selv og anden. Man finder en lignende tankegang hos Lévinas, som også fremhæver mødet med det radikalt fremmede som det afgørende i intersubjektivitetsproblematikken. Så længe vi betragter den anden som en der kan inkluderes eller integreres i en totalitet har vi, ifølge Lévinas, endnu ikke forstået den anden som anden: »Hvis man kunne besidde, begribe eller erkende den anden, så ville det ikke være en anden «. ${ }^{60}$ Lévinas argumenterer således for at det sande møde med den anden er et møde med det som hverken kan begrebsligg øres eller kategoriseres. Det er et møde med den ubegribelige og radikale fremmedhed. Den anden er ikke betinget af min egen subjektivitet, men giver sig kun til syne uafhængigt af alle systemer, kontekster og horisonter, i en form for epifani eller åbenbaring. ${ }^{61}$ I Totalité et infini retter Lévinas en kritik mod den traditionelle vesterlandske filosofi som han beskylder for at være totalitær. Den er efter hans opfattelse en magtens filosofi der er karakteriseret ved sin bestandige bevægelse af indoptagelse og reduktion. Den indoptager det fremmede og forskellige i det kendte og identiske. Den reducerer det andet til det samme. ${ }^{62}$ Det virker her oplagt at rette en tilsvarende kritik mod forsøget på at forstå andre ved at indvæve dem i en forenende fortælling. For at sige det på anden vis, man kan kritisere den 
narrative tilgang for at implicere hvad man kunne kalde en domesticering af fremmedheden.

Sartres og Lévinas' respektive redegørelse for intersubjektivitetens beskaffenhed kan kritiseres på forskellig vis. En oplagt indvending er, at jeg aldrig møder den anden $\mathrm{i}$ isolation, men altid i en kontekst. Mere specifikt, møder jeg dem indenfor rammerne af en historie med en begyndelse og en retning. Men skønt både Sartre og Lévinas mere generelt kan kritiseres for at have overset væsentlige aspekter af socialiteten og af den interpersonale sameksistens, så vil jeg samtidig mene, at de rent faktisk får peget på en helt afgørende dimension ved hvad det vil sige at møde andre; et element eller en dimension som jeg netop frygter at den narrative tilgang taber af syne. Den andens fremmedhed er netop det som modsætter sig eller overskrider de historier som vi fortæller om ham eller hende. Endnu engang går Schapp således for radikalt til værks. In Geschichten Verstrickt hævder han at det eneste der er vigtigt ved andre er deres historier. Mødet med den anden i kød og blod, det konkrete møde ansigt-til-ansigt tilføjer ikke noget nyt, peger ikke udover fortællingen. Schapp holder sig helt konsekvent til metaforen og skriver sågar at ansigtet også fortæller historier, og det at møde en ansigt-til-ansigt er som at læse i en bog. I det konkrete møde med den anden lærer vi blot nye historier at kende eller får de gamle historier bekræftet. ${ }^{63}$

\section{Konklusion}

En endelig vurdering af den narrative redegørelse for selvet må forholde sig til spørgsmål som i vidt omfang har præget den igangværende debat mellem fænomenologi og hermeneutik. Disse spørgsmål inkluderer f.eks. forholdet mellem sprog og erfaring, forholdet mellem tidslighed og historicitet, og måske mest afgørende, spørgsmålet om hvorvidt selverfaring altid og nødvendigvis er medieret af tegn og symboler; et spørgsmål som har fundet en prægnant artikulation i Ricoeurs diskussion af det han kalder det sårede cogito (cogito blessé). Jeg vil selvsagt ikke mene, at jeg i det foregående har behandler nogle af disse emner udtømmende, men jeg håber at det er blevet klart, at jeg vil afvise påstanden om at fænomenologi og hermeneutik er alternativer, der udelukker hinanden. For mig at se, har vi at gøre med komplementerende perspektiver, skønt det formentlig også er blevet klart, at jeg vil tilskrive en vis prioritet til det fænomenologiske perspektiv, og derfor også må tage afstand fra det synspunkt som f.eks. er blevet forfægtet af Charles Taylor. For Taylor er selvet en form for væren, der kun kan eksisterer i et normativt rum, og han hævder derfor at ethvert forsøg på at definere selvet gennem en 
minimal eller formal form for selvbevidsthed må fejle, da et sådant selv enten er ikke-eksisterende eller ubetydeligt. ${ }^{64}$ For at repetere: En teori om selvet som ignorerer den fundamentale beskaffenhed af vores oplevelser er en no starter. En korrekt beskrivelse og redegørelse for den oplevelsesmæssige dimension må nødvendigvis yde første-persons perspektivet og den primitive form for selvreference som knytter sig hertil retfærdighed. Ingen af de narrative teorier, som jeg er bekendt med, har - for så vidt de overhovedet er opmærksomme på problemet - bare tilnærmelsesvis været i stand til at vise at første-personlig givethed er konstitueret af narrative strukturer. Når det kommer til stykket er denne fiasko ikke så underlig, eftersom det som tidligere nævnt i virkeligheden forholder sig omvendt. For at kunne fortælle historier om ens egne oplevelser og handlinger må man allerede være i besiddelse af et første-persons perspektiv. Påstanden om at en oplevelse først bliver min det øjeblik jeg fortæller en historie herom er ganske enkelt forkert.

Jeg har en vis sympati for den narrative model, og for den generelle antagelse om, at hvem jeg er, afhænger af hvad der betyder noget for mig, hvorfor spørgsmålet ikke kan afgøres uafhængigt af min egen selvforståelse. Men jeg mener ikke at denne model kan stå alene. Den må suppleres af en redegørelse for selvet som i højere grad yder første-persons perspektivet retfærdighed. Det er derfor at jeg har argumenteret for, at det er nødvendigt at operere med et mere primitivt og fundamentalt begreb om selv end det som narrativisterne har fokuseret på; et begreb som ikke kan indfanges af eller reduceres til narrative strukturer. I en parallel bevægelse har jeg argumenteret for, at der er en afgørende dimension ved det at være anden som den narrative model også går fejl af. Jeg har således forsvaret det synspunkt, at der er grænser for den forståelse af selv og anden som fortællinger kan bibringe. Et af de spørgsmål som så stadig står ubesvaret hen er, om der er en form for systematisk kobling mellem disse to begrænsninger. Svaret synes at ligge lige for - skønt det næppe ville være et som Lévinas ville påskønne: Grunden til at den anden er karakteriseret ved en form for utilgxngelighed og transcendens, grunden til at den anden er en anden, er netop fordi den anden også er et selv, med sit helt eget uerstattelige første-persons perspektiv. ${ }^{65}$

\section{Noter}

1 J. Bruner: Making Stories: Law, Literature, Life, Cambridge, MA 2002, p. 14.

2 M. Schechtman: The Constitution of Selves, Ithaca 1996, p. 97.

3 P. Ricoeur: Temps et récit III: Le temps raconté, Paris 1985, p. 439.

4 Schechtman, p. 94. 
5 A. MacIntyre: After virtue: A study in moral theory, London 1985, p. 205

6 E. Husserl: Cartesianische Meditationen und Pariser Vorträge, Husserliana I, Den Haag 1950, p. 109.

7 Bruner, p. 65.

8 D. A. Jopling: Self-knowledge and the self, London 2000, p. 137.

9 MacIntyre, p. 221.

10 E. Husserl: Zur Phänomenologie der Intersubjektivität II, Husserliana XIV, Den Haag 1973, p. 223.

11 Ricoeur, p. 443.

12 Op.cit., p. 443.

13 Op.cit., p. 446.

14 Bruner, pp. 12-13.

15 D. C. Dennett: Consciousness Explained, Boston 1991, p. 418; »The Self as the Center of Narrative Gravity «, in F. S. Kessel, P. M. Cole and D. L. Johnson (eds.): Self and Consciousness: Multiple Perspectives, Hillsdale 1992.

16 L. O. Mink: »History and Fiction as Modes of Comprehension«, New Literary History 1, 541-58, p. 558.

17 D. Carr: Time, Narrative, and History, Bloomington 1986, p. 59.

18 D. Carr: »Discussion: Ricoeur on Narrative", in D. Wood (ed.): On Paul Ricoeur: Narrative and Interpretation, London 1991, p. 162.

19 Carr 1986, p. 90.

20 W. Schapp: In Geschichten verstrickt, Frankfurt am Main 2004 (orig. 1953), pp. 123, 126, 136, 160.

21 A. Damasio: The Feeling of What Happens, San Diego 1999, p. 19.

22 Op.cit., pp. 7, 10, 127.

23 Op.cit, pp. 16-17, 127.

24 Op.cit, p. 175.

25 T. Metzinger: Being No One, Cambridge, MA 2003, pp. 5, 157, 303.

26 Op.cit., pp. 158, 267, 291, 626.

27 J.-P. Sartre: L'être et le néant, Paris 1976 (orig.1943), p. 142.

28 Op.cit., p. 114.

29 M. Merleau-Ponty: Phénoménologie de la perception, Paris 1945, p. 467.

30 Op.cit., pp. 487-488.

31 E. Husserl: Die Bernauer Manuskripte über das Zeitbewusstsein (1917-18), Husserliana XXXIII, Dordrecht 2001, pp. 44, 46.

32 E. Husserl: Formale und Transzendentale Logik, Husserliana XVII, Den Haag 1974, pp. 279-280; Ideen zu einer reinen Phänomenologie und phänomenologischen Philosophie II, Husserliana IV, Den Haag 1952, p. 118.

33 M. Henry: De la subjectivité, Paris 2003, p. 52.

34 M. Heidegger: Zur Bestimmung der Philosophie, Gesamtausgabe Band 56/57, Frankfurt am Main 1999.

35 Damasio op.cit., pp. 7, 308.

36 Metzinger op.cit., p. 271.

37 Eftersom fænomenologerne typisk ville benægte at selvet er et objekt, det være sig et indre eller et ydre, er det rimeligt at spørge, om det ikke snarere er Metzinger selv, som begiver sig af med tingsliggørelser.

38 Op.cit., pp. 1, 564-565.

39 Jf. D. Zahavi: »Being Someone«, Psyche 11/5 (2005).

40 Jf. J.-L. Bermúdez: The Paradox of Self-Consciousness, Cambridge, MA 1998; 
D. Zahavi: Self-Awareness and Alterity. A phenomenological Investigation, Evanston 1999; Zahavi: »Førsproglig Selvbevidsthed «, in D. Zahavi \& G. Christensen (eds.): Subjektivitet og Videnskab. Bevidsthedsforskning $i$ det 21. Arbundrede, Frederiksberg 2003.

41 Carr op.cit., p. 97.

42 A. P. Kerby: Narrative and the Self, Bloomington 1991, p. 32.

43 Bruner op.cit., pp. 86, 119.

44 L. Snyder: Speaking our Minds: Personal Reflections from Individuals with Alzheimer's, New York 2000, p. 44.

45 Jf. Snyder op.cit., p. 72.

46 Damasio op.cit., pp. 17, 116-119.

47 Her kan det også være værd at erindre sig at det latinske persona refererer til masker båret af skuespillere og at det er relateret til udtrykket dramatis personae, der som bekendt betegner karaktererne i et stykke eller i en historie. Hermed ikke være sagt, at jeg vil tilslutte mig ideen om at personen er en fiktion eller en blot maske (der tildækker det egentligt primitive kerne selv). Min pointe er blot, at der rent etymologisk er en forbindelse mellem fortællinger og det oprindelige personbegreb.

48 J. G. Hart: The Person and the Common Life, Dordrecht 1992, pp. 52-54.

49 Moland: »Ideals, Ethics, and Personhood «, in H. Ikäheimo, J. Kotkavirta, A. Laitinen \& P. Lyyra (eds.): Personhood, Jyväskylä 2004.

50 Husserl 1973, p. 175.

51 Jf. J. Parnas: »Self and Schizophrenia: A Phenomenological Perspective«, in T. Kircher \& A. David (eds.): The Self in Neuroscience and Psychiatry, Cambridge 2003 .

52 D. D. Hutto: »The Story of the Self: The Narrative Basis of Self-Development ", in K. Simms (ed.): Critical Studies: Ethics and the Subject, Amsterdam 1997; Bruner op.cit., p. 16.

53 Jf. D. D. Hutto: »The Narrative Practice Hypothesis", in D.D. Hutto (ed.): Narrative and Understanding Persons, Cambridge 2007.

54 E. Fivaz-Depeursinge, N. Favez \& F. Frascarolo: »Threesome intersubjectivity in infancy", in D. Zahavi, T. Grünbaum, \& J. Parnas (eds.): The structure and development of self-consciousness: Interdisciplinary perspectives, Amsterdam 2004.

55 Jf. Carr 1991, p. 162.

56 D. Stern: The interpersonal world of the infant, New York 1985; P. Rochat: The infant's world, Cambridge, MA 2001.

57 Jf. D. Zahavi: «Expression and empathy«, In D. Hutto \& M. Ratcliffe (eds.): Folk Psychology Reassessed, Dordrecht 2007.

58 Husserl 1950, p. 139.

59 Sartre 1976, pp. 302-3, 317.

60 E. Lévinas: Le temps et l'autre, Paris 1979, p. 83.

61 E. Lévinas: Totalité et infini, Dordrecht 1990 (orig. 1961), p. 70.

62 Op.cit., pp. 33, 38.

63 Schapp 1953, pp. 105-106.

64 C. Taylor: Sources of the Self, Cambridge, MA 1989, pp. 49.

65 For en mere udførlig diskussion af en række af de emner som er behandlet i indeværende artikel, jf. Zahavi 1999; »Selvet i filosofisk belysning «, in P. Bertelsen, M. Hermansen \& J. Tønnesvang (eds.): Vinkler på selvet-en an- 
tologi om selvbegrebets anvendelse $i$ psykologien, Århus 2002; Subjectivity and Selfhood: Investigating the first-person perspective, Cambridge, MA 2005. Det foreliggende arbejde har været støttet af en bevilling fra Danmarks Grundforskningsfond. 
